\title{
Highways to Hell? Paths Towards the Formal Financial Exclusion: Empirical Lessons of the Households from Northern Hungary
}

\author{
Márton Gosztonyi ${ }^{1}$ - Dániel Havran ${ }^{2}$ (D)
}

Accepted: 7 June 2021 / Published online: 29 July 2021

(c) The Author(s) 2021

\begin{abstract}
Whenever a household faces lack of banking payment services and access to funding, it often constraints their everyday activities and the chance to avail the financial services again. Our study explores the possible explanations of why a household becomes financially excluded in an underdeveloped area of Northern Hungary. By using a questionnaire $(n=502)$ in the spring of 2019, we conducted a covariancebased SEM analysis for detecting the key reasons. We find that the low level of income, high ratio of financial problems and high intensity of short-term borrowings equally and directly contribute to the financial exclusion of the households. Furthermore, we could not confirm any direct effects of the banking service availability, although bank services significantly influence an intermediary factor, which is the increasing repayment problem in the social environment. Our results verify the responsibility of the regulation in lending and debt collection to achieve a better social policy.
\end{abstract}

Keywords Financial exclusion · Access to finance · Northern Hungary · Household finance $\cdot$ Structural equation modelling

\section{Résumé}

Sans accès aux services bancaires ni au crédit, un ménage voit souvent ses activités limitées au quotidien et n'a pas la possibilité de recourir à nouveau à des services financiers. Notre étude explore les explications possibles et les raisons qui poussent un ménage vers l'exclusion financière dans une zone sous-développée du nord de la Hongrie. Pour en détecter les principales raisons, nous avons utilisé un questionnaire $(\mathrm{n}=$ 502) au printemps 2019 et avons réalisé une analyse par la modélisation d'équations

Dániel Havran

daniel.havran@uni-corvinus.hu

1 Budapest LAB Enterprise Development Center, Budapest Business School University of Applied Sciences, 1087, Budapest, Berzsenyi str 6, Hungary

2 Department of Finance, Corvinus University of Budapest, 1093 Budapest, Fôvám sqr 8, Hungary 
structurelles (MES) basée sur la covariance. Nous constatons que le faible niveau de revenus, le ratio élevé de problèmes financiers et de nombreux d'emprunts à court terme contribuent directement et de façon égale à l'exclusion financière des ménages. Par ailleurs, nous n'avons pas pu confirmer les effets directs de la disponibilité des services bancaires, bien que les services bancaires aient une influence significative sur un facteur intermédiaire : le problème grandissant de remboursement dans cet environnement social. Nos résultats viennent confirmer que pour parvenir à une meilleure politique sociale, la réglementation en matière de crédit et de recouvrement des dettes porte une responsabilité.

\section{Introduction}

Financial services are elementary tools of households in achieving their everyday life goals. On the one hand, access to finance may enhance the chances of going from middle class from poverty. On the other, the literature contests the positive role of financial products, namely if money is lent irresponsibly (Cherednychenko and Meindertsma 2019), then debt overhang may accelerate social exclusion (Micklitz and Domurath 2015) and high-debt burden may cause health problems such as cancer (Gilligan et al. 2018). Among the most vulnerable people in the society, debt overhang often results in financial exclusion, which is defined as 'a process whereby people encounter difficulties accessing and/or using financial services and products in the mainstream markets that are appropriate to their needs and enable them to lead a normal social life in the society in which they belong' (Anderloni et al. 2008, p. 4).

Bhalla and Lapeyre (1999) shed light on globalisation leading to social polarisation in Hungary and Poland. Their examples demonstrate that a large number of people trapped in precarious and often informal forms of work in parallel with unemployment become socially excluded and impoverished. This phenomenon still exists 20 years later in the low-income part of the society. Household members face uncertainty around their employment, social isolation and the disadvantages of spatial distribution in rural areas.

These vulnerable households tend to use both formal and informal credits because the formal bank sector often screens them out. Spatial accessibility to banking services (Martin-Oliver 2019) and the inefficiency of the financial sectors to provide appropriate services (Yah and Mbotta Ntjen 2018) are also real reasons of financial exclusion. The symbiosis of the formal and informal loans described by Jain (1999) seems to be in effect on the personal loan market as well. Being partially or entirely excluded from the banking services builds more barriers returning to the formal job market. Moreover, households with overdue debt usually prefer to work informally and hide from debt collectors, often outside government regulation (Chen 2014). By analysing the determinants of financial product usage in South Africa, Kostov et al. (2012) found that removing supply-side constraints of financial services alone itself does not necessarily expand access to finance and improve the chance for growth.

Although our study focuses on the access of finance (being excluded unintentionally), we note that the willingness to use may also imply financial exclusion, 
which heavily depends on the social trust among households (Xu 2020). Aversion of uncertainty, religion, gender and culture are considered as the most determinative reasons for trust in financial institutions. Ahunov and Van Hove (2020) show that uncertainty avoidance has a significant negative effect on trust in banks. Many macro-level studies (such as Glaeser et al. 2000; Guiso et al. 2003; Kim et al. 2018) highlight the importance of religion, while others (e.g. Adegbite and Machethe 2020 or Zins and Weill 2016) expose the role of gender gap in the access to financial services. Our study contributes to the literature by showing that in case of poor consumer's protection, low-income indebted households may be permanently excluded. Thus, we look for the demand- and supply-side constraint determinants of using financial services on the margin of the society as well.

The general question we investigate is how and to what extent the process toward financial exclusion is influenced by (1) the income-generating capacity of households, (2) the social environment, (3) the loan usage (credit history) of households and (4) the physical availability of banking services in a particular rural area in Northern Hungary, which belongs to the poorest $5 \%$ of the nomenclature of territorial units for statistics level 2 (NUTS-2) regions in the European Union (EU). The chosen region, the rural segment of Borsod-Abaúj-Zemplén County, represents a large number of households in a bad financial situation, allowing us to concentrate on one culturally and socially unified area. The ratio of deprived Roma people is particularly high in the observed area, who are heavily threatened by financial exclusion, which is related to former bad credit history, which may further transform into a debt spiral or trap. We investigate the economic (non-psychological) factors of this transformation. Our findings not only identify the problem of regions falling behind but also enhance the dispute on reducing financial exclusion of disadvantaged social and ethnic groups through the digitalisation of the economy.

To better understand factors leading to financial exclusion, we carried out a survey $(n=502)$ in the region and built a conceptual framework explaining financial exclusion pathways. We employed covariance-based structural equation modelling to test our hypotheses which reveals a direct relationship between the measured and latent variables, helping us create an interpretative framework to explain micro-level observations at the mezzo/macro-level.

We find that the lower the level of income, the higher the ratio of financial problems in the social environment and that high-intensity short-term borrowings equally and directly contribute to the financial exclusion of households. We cannot confirm any direct effects of the banking service supply on the exclusion; however, bank services significantly influence an intermediary factor-the increasing repayment problems in the social environment. In contrast to our aims related to the housing loan collapse in Hungary after the 2008 crisis, former loan-term loan usage did not significantly increase financial exclusion chances. Further, the direct effect of repayment issues in the social environment to financial exclusion suggests that banks apply credit rationing for those who have similar characters and credit application scores to the formerly bankrupted peers. The results also highlight the indisputable role of short-term loan products, which intermediate the effects of the low level of income; such loans are more harmful than useful for poor households. 
Considering the social policy implications, our results suggest that banking regulation cannot mitigate the danger of becoming financially excluded without effective income policy and debt settlement actions.

The remainder of the study proceeds as follows. An overview of the preliminary results of the explanations for financial exclusion is discussed next, followed by an introduction of the sample and the applied method. In the empirical analysis section, we explore the results of the structural equation modelling. Further investigation is presented then along with policy implications, followed by the conclusion.

\section{Literature and Context}

In this study, financial exclusion primarily refers to the lack of access to formal bank loans and forced abstention of bank debit. We do not consider other non-elementary financial products pertaining to insurance or investments. We take the substitution effect of informal financial possibilities into account. Notably, informal lending exists because of the lower information asymmetry between the lender and the borrower. However, it often leads to unethical consequences.

Financial exclusion also reflects a phenomenon embedded in a network of complex and multi-level social exclusion of low-income population, which includes the households' deprivation of social and financial opportunities, as Leyshon and Thrift (1996) describes. It also signifies that a group in the society is prevented from acquiring any financial system services which often goes hand in hand with social exclusion (Anderloni and Carluccio 2006; Anderloni et al. 2008, p. 10).

There are several explanations as to why households take bank loans beyond their capacities. A major part of the literature explains debt overhang with the lack of financial literacy or financial imprudence, such as in studies by Hilgert et al. (2003); Disney et al. (2008); and Lusardi and Tufano (2009). Many a times, households underestimate the probability of future adverse events (Kilborn 2005) and enter carelessly into a debt contract. However, Campbell (2006) states that only the poorer and the less educated minorities in US households make significant mistakes. The second group of theories is related to over-consumption and particularly its psychological causes. Research reveals the main psychological attributes of borrowing consumer debt (Lea et al. 1995) and credit-card debt (Norvilitis et al. 2006). The literature on the causal chain of over-consumption also includes a study by Garðarsdóttir and Dittmar (2012), who conclude that ' $[\mathrm{bad}]$ money management skills and greater tendency towards compulsive buying and spending' (471) induce debt overhangs and the pressure of the consumer society does not influence only the disadvantaged families. The third group of arguments is about loans to cover unexpected expenses of households and the lack of emergency savings (Keese 2009). The main types of liquidity shocks are negative events such as illnesses, loss of job, medical expenses or changes in the family structure. At that time, households do not judge their future financial conditions.

Even if households evict a loan that seems to be in their capacity, there is a huge possibility that they will still go bankrupt. Fay et al. (2002) found that bankruptcy filing could be advantageous for the US households; however, there 
is little evidence on the households choosing bankruptcy in a conscious, strategical way. Refusing redemption can be either a rational or an irrational decision. When an unexpected liquidity shock arises in a period of redemption, it is rational, without any reservation to declare bankruptcy (Big Lottery Fund 2018). In many cases, non-payment may work as a social or healthcare insurance (Dobbie and Song 2015; Mahoney 2015). Behavioural factors also play a role in household defaults, such as persons with low self-efficacy (the perception of the benefits from acting) go bankrupt more often (Kuhnen and Melzer 2018), and personality attributes also influence repayment behaviours (Parise and Peijnenburg 2019).

After bankruptcy, the debt collector could claim a lump-sum redemption, restructure the payments ('repayment plan') or start the recovery procedure wherein the household's private assets can be seized. The regulation environment for the remission of debt differs across countries; the major concepts of private bankruptcy regulations originate from the Anglo-Saxon, the Continental (European) and the Scandinavian legal frameworks. However, little is known about those who became financially excluded after bankruptcy. Further, the defaulted households may face financial distress in a trapped situation, getting out of which is difficult and can lead to a state of learned helplessness and apathy. There are a few lessons about such negative spill-over effects. In a sociological study of a Hungarian village, Gosztonyi (2017) found interpersonal and informal lending where families faced serious debt payment disorders. Informal networks function as an insurance risk community against individual liquidity shocks. However, these networks hold back individual savings as such reserves are transferred to the just-in-need community members.

There are job market and macro-financial drawbacks of these financial distresses. Using US household data, Bernstein (2015) reports that negative home equity (mortgage) causes a $2-6 \%$ reduction in household labour supply. Considering the post-socialist countries in Europe, low-income households responded to the shortages of the formal labour market and their exclusion from formal banking institutions by special survival strategies (Fleck and Virág 2000; Kovai 2017; Danyi and Vigvári 2019). Macro-effects of household debts and the nonperformed loans have been often investigated, such as by Rinaldi and SanchisArellano (2006) and Lombardi et al. (2017). Unfortunately, Beck and Brown (2011) found that state bank ownership does not induce financial inclusion for rural or poor urban households.

There are only a few studies in the literature describing the financial exclusion pathways. A notable one by D'Alessio and Iezzi (2013) carried out a framework to measure over-indebtedness and applied it on Italian observations. Many related applications of the structural equation modelling reveal determinants of social exclusion without having to investigate financial dimensions. For example, Hajdu (2009) studied a Hungarian sample, while Ruesga-Benito et al. (2018) examined socially excluded young adults in the EU. However, to our best knowledge, there is no empirical data revealing a direct or indirect relationship between formal financial exclusion and their determining factors. We aim to close this gap by examining the roles of these factors. 


\section{Data and Conceptual Framework}

\section{Overview of the Sample}

Our observed region, Borsod-Abaúj-Zemplén County, has a fragmented village structure, with many socioeconomically disadvantaged inhabitants, compared to other Hungarian areas. Figure 1 illustrates the geographical location of the survey, roughly representing European districts where households facing problems with unexpected expenses are relatively high in number (on the left). An empirical report by Fondeville et al. (2010) emphasises that indebtedness and defaults of households are major problems in Eastern Europe. The figure also shows the 57 municipalities included in the sample (on the right); they are marked green. The dots on the map indicate the placements of bank (red) or saving cooperative (green) branches.

The survey is restricted to the Borsod-Abaúj-Zemplén County households and families residing in a small rural settlement, relatively far from bank branches. Following Banerjee and Duflo's (2007) argument on debt that decisions in rural households are not usually made on an individual but a household level, the analysed unit used is that of the household. Since low-income rural residents are less likely to answer online or telephonic questionnaires, we carried out face-to-face interviewers to get reliable data in the local debt trap context.

The sample was selected in two stages. In the first stage, we determined the target population that consists of 342 settlements (107,153 households; 282,504 inhabitants). Then, we chose the sample from 57 settlements based on a probability sampling at $95 \%$ confidence level and $\pm 11.87 \%$ margin of error. In the second stage, we calculated quotas for the population of the households of $n=31,122(86,146$ residents); following this, interviews were carried out by random walk sampling in each of the settlements (5-15 randomly selected households). The municipality mayors were notified two weeks in advance for the interviews. The interviewees
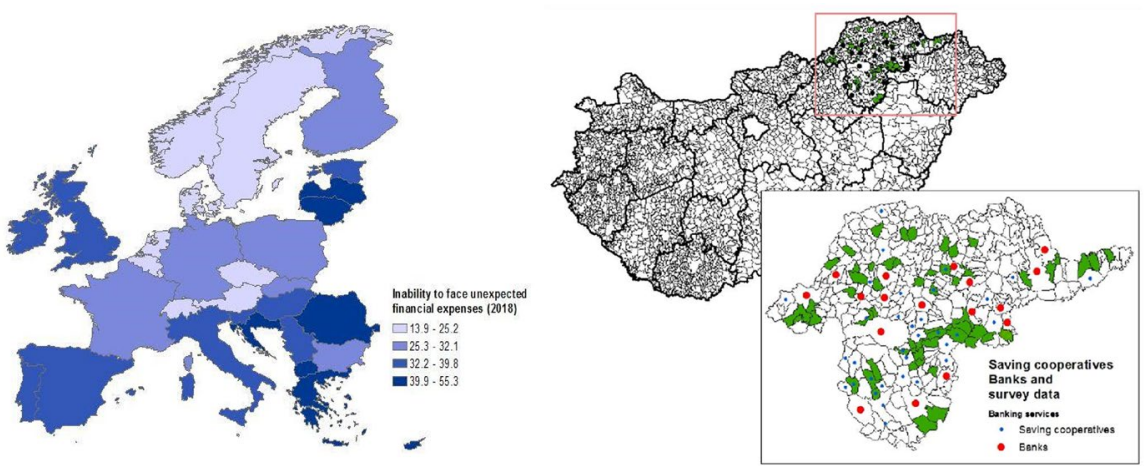

Fig. 1 Geographical identification. Left: European countries with high proportion of households facing problems with unexpected financial expenses (Source Eurostat (2019), Civic Consulting based on Eurostat, SILC data). Right: Map of Hungary and Borsod-Abaúj-Zemplén County with the investigated micro-regions (Source Authors; the survey was conducted in the green zones; red dots: bank branches; green dots: post offices. Made by ArcGIS 10.4) 
were adults (18+years). Data was collected from 504 households between March and April 2019, and after excluding the extremes, we kept 502 observations. At $95 \%$ confidence level, $n=502$ sample size, the margin of error was $\pm 4.34 \%$ (considering 107,153 households at $95 \%$ confidence level, $n=502$ sample size results in a $4.36 \%$ confidence interval).

Table 1 summarises the descriptive statistics on households as the observational units. There is a perceptible over-representation of the female respondents (71\%), who answered questions related to the households. Usually, females received the interviewer as they were housewives; moreover, in Hungarian and Roma households, they are responsible for financial and familial issues. The observed data verifies that male respondents more likely belonged to single households and female respondents represented families of 2 to 6 . As our aim was to evaluate mechanisms on the household level, we decided to use this household-focused sample to investigate the gender bias and gender effects for further analysis. We also found (not denoted in the table) that $41 \%$ of the respondents belong to Roma ethnicity which is higher than the average $(8.5 \%)$ of the county. The difference can be explained by the higher Roma population ratio in smaller settlements. The ethnicity was assessed by

Table 1 Region overview: descriptive statistics from the survey sample $(n=502)$

\begin{tabular}{llll}
\hline Statistics & Value & Statistics & Value \\
\hline Respondents & & Loan history of the households \\
Female (\%) & 71.31 & $\begin{array}{l}\text { Covered loan (\%) (e.g. mortgage, auto } \\
\text { loans) }\end{array}$ & 13.5 \\
Age (average) & 44.44 & Uncovered loan (\%) (e.g. personal loans) & 27.1 \\
No bank account (\%) & 40.52 & Arrears in covered loan repayment (\%) & 5.8 \\
College/university degree (\%) & 4.98 & Arrears in uncovered loan repayment (\%) & 12.2 \\
Secondary school (\%) & 19.72 & Under recovery procedure (\%) & 15.1 \\
Vocational education (\%) & 29.88 & Loan from family (\%) & 39.4 \\
Elementary school (\%) & 38.05 & Loan from others ${ }^{\text {a }}(\%)$ & 12.9 \\
Elementary: not finished (\%) & 7.37 & Usury (\%) & 2.6 \\
Household income and labour market & & Financial service availability in the settle- & \\
$\quad$ situation & & ment & 100.0 \\
Household net income, EUR (monthly, & 729.8 & No bank branch (\%) & 71.5 \\
$\quad$ mean) & & & 75.1 \\
Household net income, EUR (monthly, & 460.9 & No ATMs (\%) & 16.9 \\
$\quad$ st. dev.) & & & \\
Household members (average) & 3.57 & No savings cooperatives (\%) & \\
Full-time employed (\%) & 28.9 & No post office (\%) & \\
Public work (\%) & 15.1 & & \\
Unemployed (\%) & 5.9 & & \\
Retired (\%) & 11.5 & & \\
Student (\%) & 2.3 & & \\
Maternity leave (\%) & 3.7 & & \\
\hline
\end{tabular}

${ }^{a}$ Loan from others in the answers often mean usury 
the interviewer. $40.52 \%$ of the respondents did not have bank accounts (altogether, $29 \%$ of the households reported absence of bank accounts). The level of education shows a high variety among the respondents. The average monthly net income of the households was around EUR 730, which is around EUR 386 per capita, according to the OECD equivalence scale (household income by the square root of the household size). In comparison, in the first half of 2019, the average monthly net income was EUR 566 in Borsod-Abaúj-Zemplén County and EUR 724 in Hungary. The table provides insights on household loan history and accessibility to financial services.

\section{Conceptual Framework}

In this section, we introduce our conceptual framework and explain the assumed relationships among the key factors. Our main objective is to reveal the determinants of formal financial exclusion. We capture formal financial exclusion with actions that are taken because households are constrained to using formal financial services, such as bank accounts and bank loans. Hence, our research focuses on the access rather than the (willingness of) use of financial services. We investigate four major alternating explanations which can be considered the determining factors.

The first is the low-income-generating capacity, which mostly goes together with social exclusion. In the case of low-income households, loans or debit products cannot be used in the regular way because the borrowers cannot pay back the amount; thus, lower income may subserve exclusion. Income-generating capacity may influence the short-term and long-term loan usage as well. It may also positively correlate with current financial difficulties arising in the social environment of households.

The second factor is the lack of availability of banking services, which means high transaction costs for banking. Spatial segregation, technical barriers or highdebt collecting costs (thus, high interest rates on personal loans) may make it more difficult to access financial services. This availability may strengthen access to finances and may decrease the chances of financial exclusion. Income may correlate with the presence of financial services; banks may offer less services to the poorer areas.

The third is the drawbacks of information asymmetry. We identify this phenomenon under the negative consequences of default in the social network, which indicates that the social environment of a household experiences more negative consequences with loan repayment problems. Appearing financial difficulties in the social network decreases the chance of access to finance, hence lenders cannot distinguish between the reliable and problematic households during loan application. Because of the higher information asymmetry, solvent households will more likely be rejected by banks.

The fourth one is the bad credit history of households. Former defaults or present unpaid debentures predict poor repayment and saving behaviour. Moreover, too much debt could be an impeding factor in access to formal finance, even if the debtor meets their obligations. This situation may also bring in serious redemption problems if an income shock arises. Repayment difficulties may lead to bankruptcy, recovery 
procedure and financial exclusion. Instead of explicitly investigating the underlying bad credit histories (for example, poor financial literacy, consumption commitment issues, unexpected changes in the family or employment status, health problems or unexpected income shocks), we are concentrating on the key determinants and consequences. To learn more about the transmitting mechanisms, we consider the roles of short-term and long-term loans in a different way. Short-term borrowing could mean that households face daily living problems. Short-term loan usage can be influenced by income-generating capacity, defaults in the social network or bank service availability. Long-term loans could cover durable goods or a home, which can be linked to a higher income. However, bankrupted mortgages may induce serious debt traps. Long-term loans can be influenced by income, social environment and banking service availability and may also correlate with short-term loan usage.

The conceptual framework suggests setting up three major hypotheses and some sub-hypotheses.

Hypothesis 1 Depth of formal financial exclusion is determined by
(A) household income,
(B) bank service availability,
(C) prevalence of defaults in the social network,
(C) short-term (D.S.)/long-term (D.L.) loan credit history.

Hypothesis 2 Level of short-term (H2.S.)/long-term (H2.L.) credit usage is determined by
(A) household income,
(B) bank service availability,
(C) prevalence of defaults in the social network.

Hypothesis 3 Prevalence of defaults in the social network is influenced by
(A) the income of the surveyed households,
(B) the bank service availability of the surveyed households.

Altogether, we have $5+2 * 3+2=13$ sub-hypotheses.

Figure 2 shows the structure of our conceptual framework which consists of the six main components. We are also curious about the covariances between long- and shortterm loan usage and income and bank service availability. These relations are indicated in Fig. 2. 


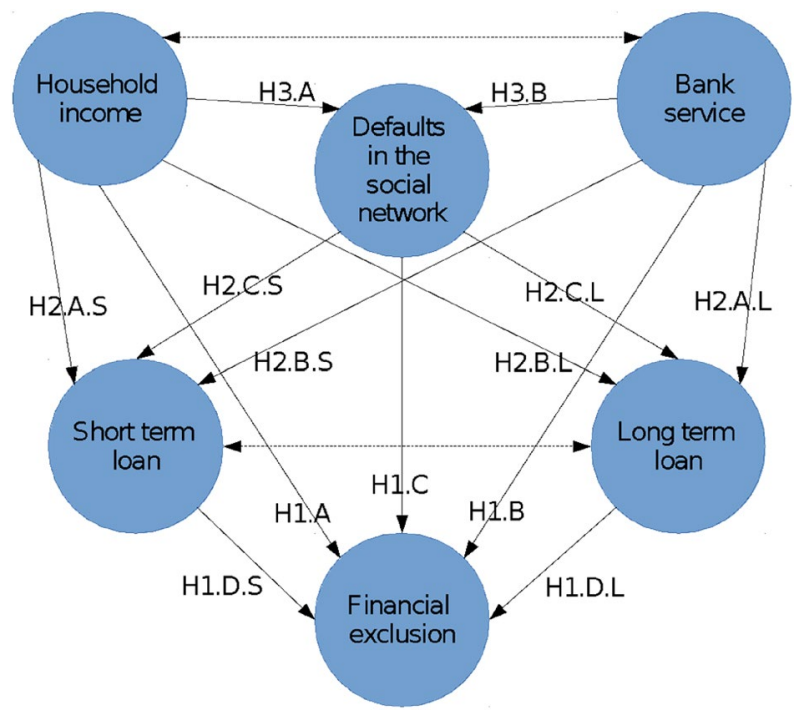

Fig. 2 The conceptual framework explaining formal financial exclusion

\section{Empirical Results}

\section{Estimation Methodology}

For testing our hypotheses, we employed covariance-based structural equation modelling (CB-SEM) with the method described by Muthén and Muthén (2004). Our estimation was carried out by $\mathrm{R}$ software (version 3.6.3) and the lavaan package (version 0.6-5).

The approach defines the equations of the following:

$$
\begin{aligned}
y_{i} & =\nu+\Lambda \eta_{i}+K x_{i}+\varepsilon_{i} \\
\eta_{i} & =\alpha+B \eta_{i}+\Gamma x_{i}+\zeta_{i}
\end{aligned}
$$

where $y$ and $\eta$ are vectors of endogenous and exogenous latent variables, $x$ is a vector of observed variables, $\nu$ is a vector of measurement intercepts, $\alpha$ is vector of latent intercepts, $\Lambda$ is a matrix of factor loadings and $K, B$ and $\Gamma$ are matrices of regression coefficients.

We used the maximum likelihood estimator with Huber/Pseudo ML/sandwich corrections (called MLR in Mplus) to determine the equation coefficients. Though our data variables typically do not come from normal distribution and the multivariate normality was not satisfied (employing Mardia's test for multivariate normality and Shapiro-Wilk test for univariate normality), the parameter estimates can still be consistent when the model is identified and correctly specified. In such cases, standard errors may tend to be too small, increasing the chance to reject the null hypothesis without a reason. Moreover, the model chi-squared test statistic may become 
too large; thus, we may reject the model too often (Rosseel 2012). MLR computes standard errors using a sandwich estimator and applied chi-square test statistic which is asymptotically equivalent to Yuan-Bentler T2-star test statistics. Thus, the standard errors and chi-square test statistics were robust to non-normality.

We ran several iterations to reach our final model during the selection of variables suggested by our conceptual framework. Based on MacCallum et al.'s (1992) method, we first tested our pre-made (a priori) conceptual model on the variable set and then continuously made alternative models and compared them to the previous ones. Only the last version is discussed in this study. For reproducibility, we publish the covariance matrix of the data in Table 5 in Appendix.

For absolute model fit criteria, we used chi squared (Bollen 1989) and Comparative Fit Index (CFI) (Bentler 1989). These criteria, described by Hoyle and Panter (1995, pp. 165-169), related to the degree to which the covariances implied by the fix and free parameters specified in the model match the observed covariances, from which free parameters in the model are estimated (Johnson 1998, p. 146). We also used the root-mean-square error of approximation (RMSEA) and the $p$ value as recommended by Browne and Cudeck (1993) to determine our model fit. Our model provided a good fit: chi squared $=544.887$, degrees of freedom $=294, p$ value $=0.000$ (Yuan-Bentler T2 test statistic), $\mathrm{CFI}=0.906, \mathrm{RMSEA}=0.41$ and the PCLOSE value $=0.9997$.

\section{Measurement Model}

To construct the latent variables, we applied a reflective measurement approach wherein measures represent the manifestations of the latent factors.

We connected formal financial exclusion with variables such as (1) a bank account at the household, (2) abstinence from using a bank account because any savings would be withdrawn by debt collectors or in household borrowings, (3) usury or (4) family loan because of rejected credit applications. We interpret usury and family borrowings as possible reactions to replace non-available formal loans.

Household income or income-generating capacity involves the measures of (1) disposable income, (2) existence of savings, (3) education as a proxy for working efficiency and ability, (4) public worker and (5) unemployment. Bank service availability is measured by (1) spatial distance of brick and mortar bank branches, the presence of (2) postal branches, (3) bank ATMs and (4) size of the settlement (village).

We describe the negative consequences of default in the social network as the survey responses about the social environment reflecting (1) constrained bank account usage; informal borrowing from (2) private persons and (3) family members; (4) pawn shop usage; property losses such as loss of (5) real or (6) personal estate; or (7) forced move to other residence. For the 'Do you know somebody' questions, the respondents denoted themselves as well; this time, the answers were counted as 'there is someone'. By repeating the estimations excluding the 'myself' answers, we did not find significant changes and evidence of inherent technical correlation. 
We identified short-term loans as personal loans (1) during repayment or (2) past due and (3) the fact of borrowing from a bank because of financial difficulties in the last one year. During the preparatory stage of this research, we did not find strong correlation with commercial credits other smaller bank loans. Therefore, we excluded them from the analysis. We describe long-term loan usage with (1) housing loans, (2) mortgage and (3) former existence of foreign exchange denominated home loans. According to our preparatory analysis, auto loans did not show significant explanatory power.

Table 2. details the observable variables form the survey and how they capture the latent variables of the conceptual framework which are verified by confirmatory factor analysis (CFA) and each of our latent variables being significant at the 0.05 level and all but two at 0.01 level. The estimated coefficients are several cases under 0.7; however, we kept these variables from theoretical considerations. Instead of creating the most well-fitted measurement model, we aimed to construct latent variables that are connected to some theoretically supported variables, despite their lower statistical explanatory power. To improve the model, after checking modification indices of the observed variables, we extended the base specification by adding some residual correlations. The selected correlated variable pairs are detailed in Table 6 in Appendix.

The internal consistency reliability was tested using Chronbach's alpha (alpha $=0.5881$ ), which was over 0.5 and acceptable, even if it is not strong. The composite reliability was above $0.7(\mathrm{CR}=0.8904)$, hence we decided to accept the model (for using it for structural modelling), even though the validity of some measurement variables show low commonality (average variance extracted is below 0.5 , in the case of defaults in social network and banking service availability variables). Divergent validity criteria (where square-root AVE > largest correlation with other factors) satisfy almost all factors, except financial exclusion and short-term loan.

\section{Structural Model}

Our structural model is designed according to the formalised hypothesis. The results confirm only five effects but clearly provide a sharper picture resolution of the major causes. Figure 3 illustrates the structures in our overall model.

We find that financial exclusion is directly determined by three major factors: the household income, the defaults in the social networks and the short-term loan usage (however, the last has $10 \%$ significance level only). These confirm that low incomes of the households accelerate formal financial exclusion (H1.A), short-term loans bring households to the brink of formal financial exclusion (H1.D.S) and more defaults in the social environment increase the vulnerability to financial exclusion (H1.C). The last relationship may be because of the credit rationing of the banks, which happens to be our main intuition. We do not expose the variety of the intrinsic mechanisms that promote credit rationing, which can be set off by similarity among the members of a social network. These usually cannot be observed at credit application, for example, financial literacy, capability of the consumption commitment, hidden interpersonal financial claims (within the family or in context of local loan 


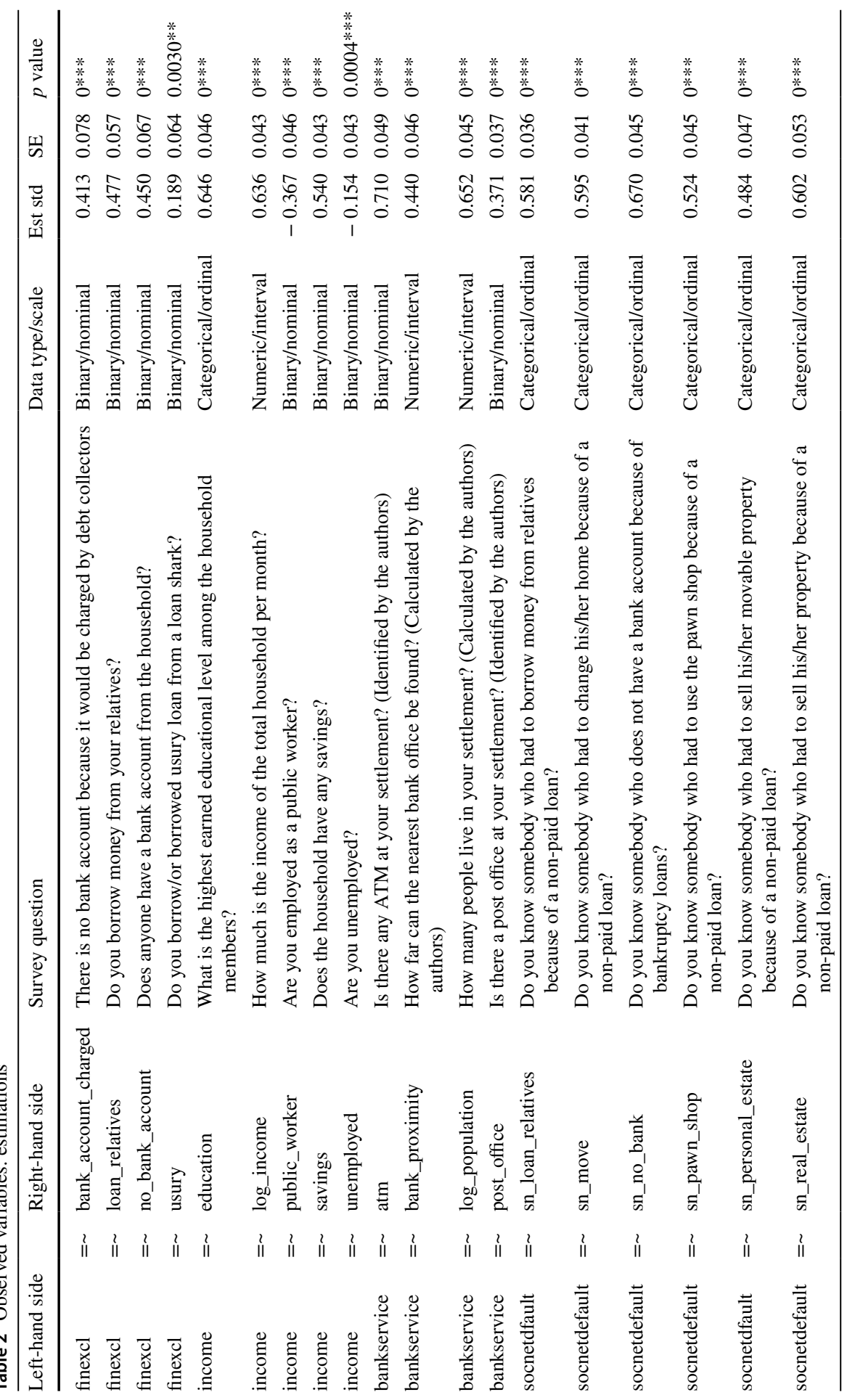




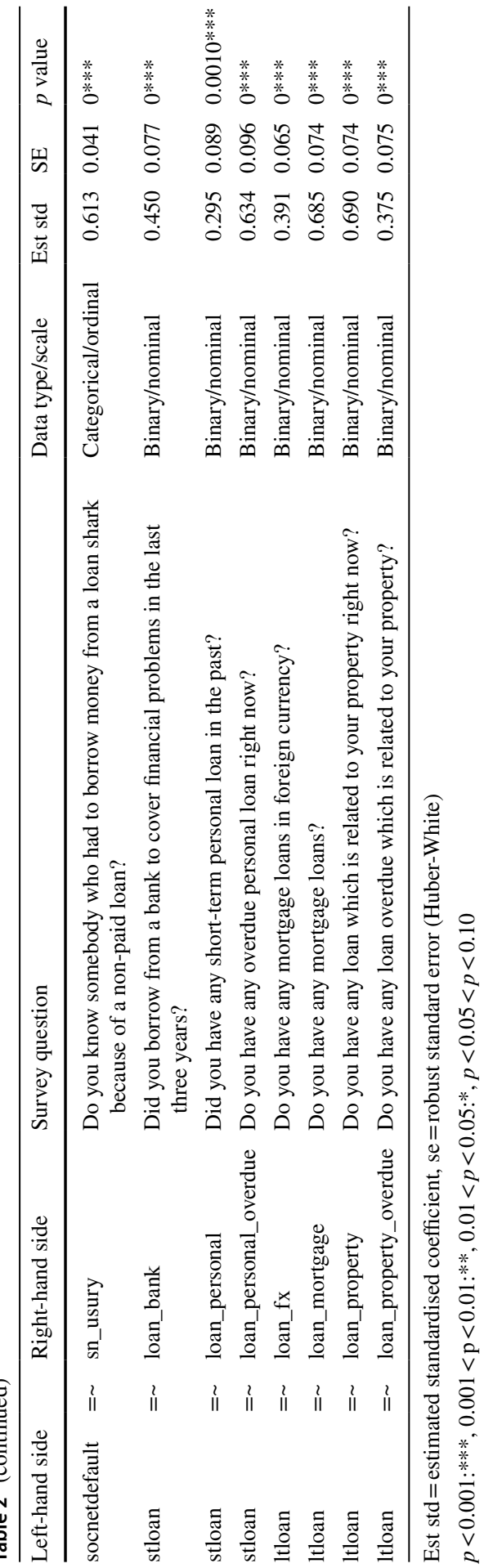

站。 


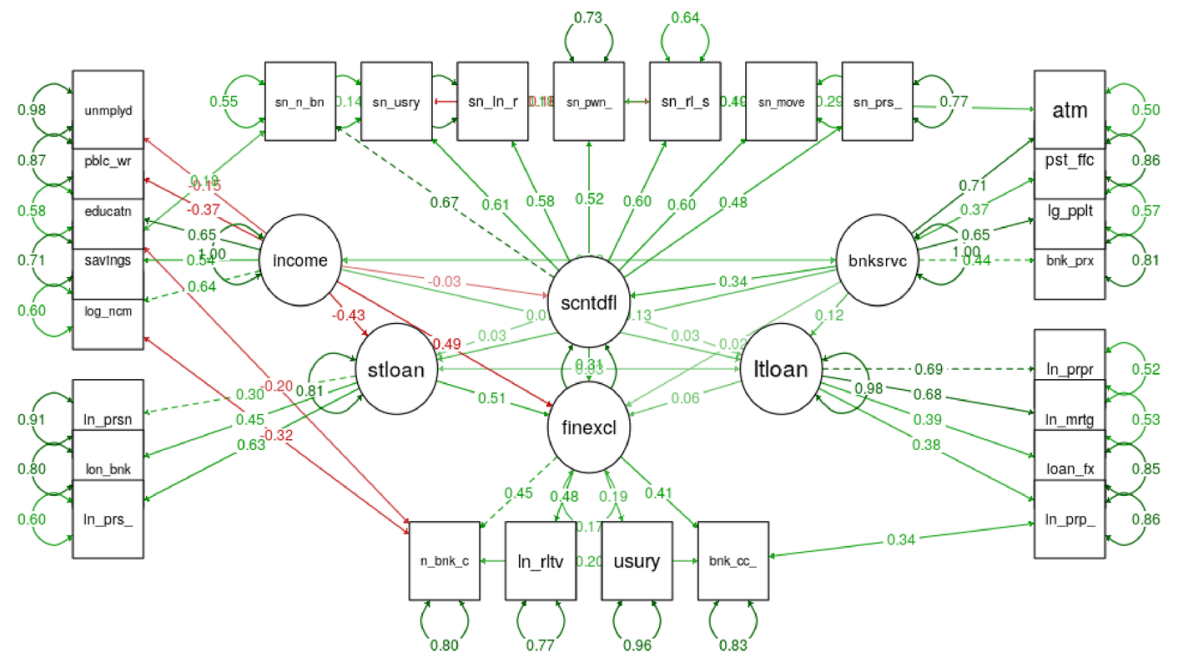

Fig. 3 Overall model

sharks) or other social situations and norms that may characterise the entire social group. We find that the H1.B hypothesis (direct effect of bank service availability) is not statistically significant. The average distance from a bank branch is $15 \mathrm{~km}$ with a range of 3-39 km; however, $16.9 \%$ of the respondents live in a settlement with no post office. The post offices offer some reduced services for initiating bank transactions, saving or even applying for a personal loan. Other substitutes, such as visiting agents of payday loan providers and mobile banking, are still available in the area.

We find two drivers of the endogenous factors. First, defaults in the social network are sensitive to the availability of the banking service (H3.B): the appearance of the defaults in the social environment is more frequent in areas with easier access to banking services. Supposing that households experiencing defaults in their environment possess worse financial literacy, we can explain why poor access to banking service is caused indirectly but not directly by financial exclusion. Second, the usage of short-term loans is more intense where household income is lower (H.2.S.A): poorer households rather need short-term borrowings from financial institutions.

By analysing the long-term loan usage, we identify banking services to be at the $10 \%$ significance level, but no other factors explain the long-term borrowings; furthermore, long-term loans do not seem to push households toward financial exclusion.

Table 3 summarises our hypothesis test findings. We conclude that low income may induce more intense short-term borrowings, and if the household cannot avail any loans, it may lead to financial exclusion. Moreover, short-term credit products may endanger households in themselves. This narrative is amplified by the fact that bank service supply facilitates financial exclusion in the social environment where bad credit history appears more prominent.

According to Table 4, two significant indirect relationships (income_stloan and bankservice_socnetdefault) are in effect in the estimated model. At first, the 


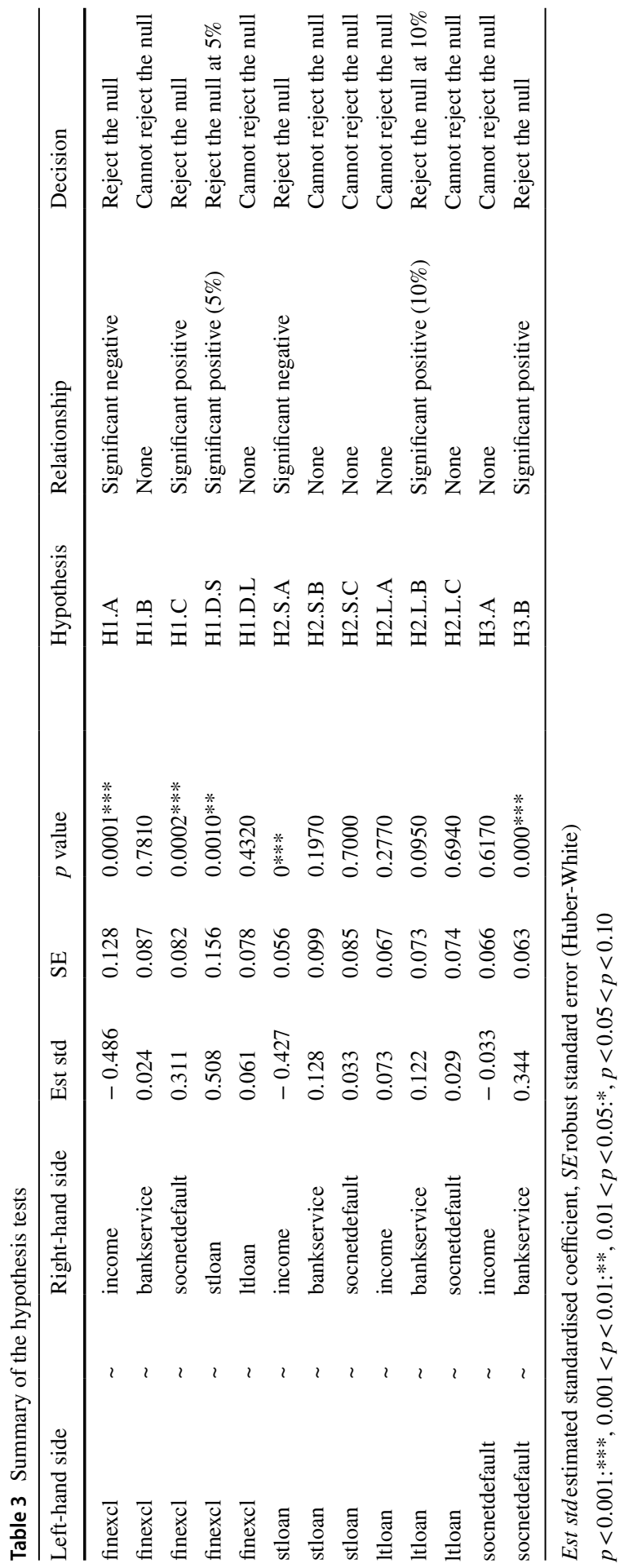

s. 
Table 4 Mediation effects in the model

\begin{tabular}{lrll}
\hline Indirect and total effects & Est std & SE & $p$ value \\
\hline income_stloan & -0.217 & 0.072 & $0.0020^{* *}$ \\
income_ltloan & 0.004 & 0.007 & 0.5300 \\
income_socnetdefault & -0.010 & 0.021 & 0.6180 \\
income_socnetdefault_stloan & -0.001 & 0.002 & 0.7580 \\
income_socnetdefault_ltloan & -0.0001 & 0.0002 & 0.7810 \\
total_income & -0.709 & 0.082 & $0 * * *$ \\
bankservice_stloan & 0.065 & 0.057 & 0.2550 \\
bankservice_ltloan & 0.007 & 0.011 & 0.4910 \\
bankservice_socnetdefault & 0.107 & 0.034 & $0.0020^{* *}$ \\
bankservice_socnetdefault_stloan & 0.006 & 0.015 & 0.7050 \\
bankservice_socnetdefault_ltloan & 0.001 & 0.002 & 0.7350 \\
total_bankservice & 0.210 & 0.091 & $0.0210^{*}$ \\
socnetdefault_stloan & 0.017 & 0.044 & 0.7080 \\
socnetdefault_ltloan & 0.002 & 0.005 & 0.7340 \\
total_socnetdefault & 0.329 & 0.085 & $0.0001^{* * *}$ \\
\hline
\end{tabular}

Est std estimated standardised coefficient, SE robust standard error (Huber-White)

$p<0.001$ :*** $^{*}, \quad 0.001<p<0.01$ : $^{* *}, \quad 0.01<p<0.05$ : $^{*}$,

short-term loan usage mediates the effect of income towards financial exclusion: income negatively influences the short-term loan, also a determinant of financial exclusion. Second, the default occurrences in the social network intermediate the effect of bank service availability (with 5\% significance): banking service availability is positively correlated with socnet_default, which fosters financial exclusion. Total effect coefficients of income and banking service availability seem to be statistically significant (the latter with $10 \%$ significance), which also bolster the hypothesis that lower income and stronger banking service availability altogether induce rather than prevent exclusion.

\section{Further Analysis}

Importantly, households in Hungary trust less in banks after the financial and FXmortgage crisis (overview by Csizmady and Hegedüs 2016). Since the wage is to be paid to the bank accounts, households are willing to use bank products if they have an employed status. Although our survey does not address direct questions for revealing trust, it offers some insights into the avoidance of the use of bank accounts. Altogether, $60 \%$ of those respondents who own no bank account answered that they do not need any. Generally, they are in a hopeless labour market situation, and there is no income to receive in a bank account. Moreover, $20 \%$ of the respondents do not use bank accounts because they are withdrawn by debt collectors (there is $7.3 \%$ overlap with the no-need answers). 
To detect the indirect effects of religion, we added the settlement-based religion data from the census of 2011 provided by the Hungarian Statistical Office to us and reported the estimated relationships in Table 7 of the Appendix. On considering the three major religions in the area (Roman Catholics, Greek Catholics, and Calvinists), we find evidence that the ratio of the Roman Catholics is negatively correlated with financial exclusion. Furthermore, gender and ethnicity may modify the bank usage behaviour patterns; the effects are summarised in Table 8 in the Appendix. The respondent's gender itself has no significant effect, but the short-term loan intensifies, while long-term loan and income weaken the original effects on females. Ethnicity significantly influences the financial exclusion score. Because of this, to reveal the validity of the main hypotheses for Roma $(n=211)$ and non-Roma $(n=291)$ households, we analyse the re-estimated model for the two sub-samples. The results of the structural models are summarised in Table 9 in the Appendix, with a note that these models are less reliable. By evaluating the analysis on Roma and non-Roma sub-samples, we learn that the model for the non-Roma population is not valid anymore. In case of the Roma, the short-term loan and defaults in the social environment factors are still in effect, suggesting that banks lend to a more vulnerable group of people.

Because financial exclusion never appears alone, we consider the spill-over effects for the labour supply behaviour, the health conditions, the future outlook and the actual living conditions of the households. By gathering answers for these attributes from the survey, we can analyse the common occurrences. We use the predicted financial exclusion factor scores and calculate averages within each category group of the six selected variables. In Table 10, group means are sorted out in decreasing order; the categories at the top of the sections are the closest to financial exclusion. Unregistered and inactive job market statuses have the highest factor scores, which is in accordance with anecdotes of 'hiding' bankrupt individuals whose wage would be charged by the debt collectors if they were registered in their workplace. Health satisfaction-which may divert to the real health situation-shows lower, but existent, dispersion due to being excluded.

Our results imply that the banking services designed for the middle-class and the punitive debt collection rules negatively impact the households that live in poverty, where there is a low chance of developing a successful small business or even landing a permanent job. The irresponsible lending of loan products intensifies consumption instead of enhancing entrepreneurial activities. As a result, an ambiguous situation arises, i.e. financial institutions do not provide economic opportunities for those living in poverty but entangle them in a debt trap and force them out of access to formal financial institutions for life, leaving them to cope with the nightmare of an irrecoverable loan contract. In response to this phenomenon, there is empirical evidence (Gosztonyi 2017; Danyi and Vígvári 2019) on the evolution of informal and archaic shadow financial institutions for low-income communities, which means effective barriers to individual savings. 


\section{Conclusion}

Based on widely accessible international literature, financial exclusion in the form of lacking access to funding can be ascertained to hinder an entrepreneur in India or African countries, dwindle individual savings or make managing payments more difficult. Sometimes, it is connected to language barriers, financial literacy, migration (cultural or religion differences) or spatial distance from physical facilities. This study aims to put another explanatory factor on a map: the short-term borrowings of impoverished households to cover their temporal shortages. According to the $\mathrm{H} 1$ set of hypotheses, we document the demand- and supply-side constraints of access to finance in case of impoverished households. In case of low income, the social environment (credit rationing) and the short-term borrowings from the formal banking sector, we find direct effects; furthermore, banking supply exerts its negative effects only through the social environment. According to the $\mathrm{H} 2$ set, short-term loans may become toxic for households wishing to maintain the former (not so high) living standards independently of their financial knowledge or literacy. We also highlight that repayment problems not only influence the loan victims but also amplify financial exclusion of their social environment as well (H3). The phenomenon is stronger, but not exclusively, in the Roma minority, which suffered from notable impoverishment in the last three decades. In our observed region, formal financial exclusion often goes hand in hand with falling off from the job market, suffering from mental depression and facing exclusion from the public utilities as well.

We, therefore, believe that it would be worthwhile to rethink and reinterpret the credit structures in semi-peripheral and peripheral countries and reconsider the recovery and debt collecting regulations. It would also be important to incorporate social network factors which play an important role in indebtedness into the credit rating processes. The challenge is to offer people living in poverty the opportunity to extricate themselves out of unofficial credit networks and, thus, develop a formal system of financial institutions that is better adapted to lowincome families.

\section{Appendix}

See Table 5, 6, 7, 8, 9, and 10 . 


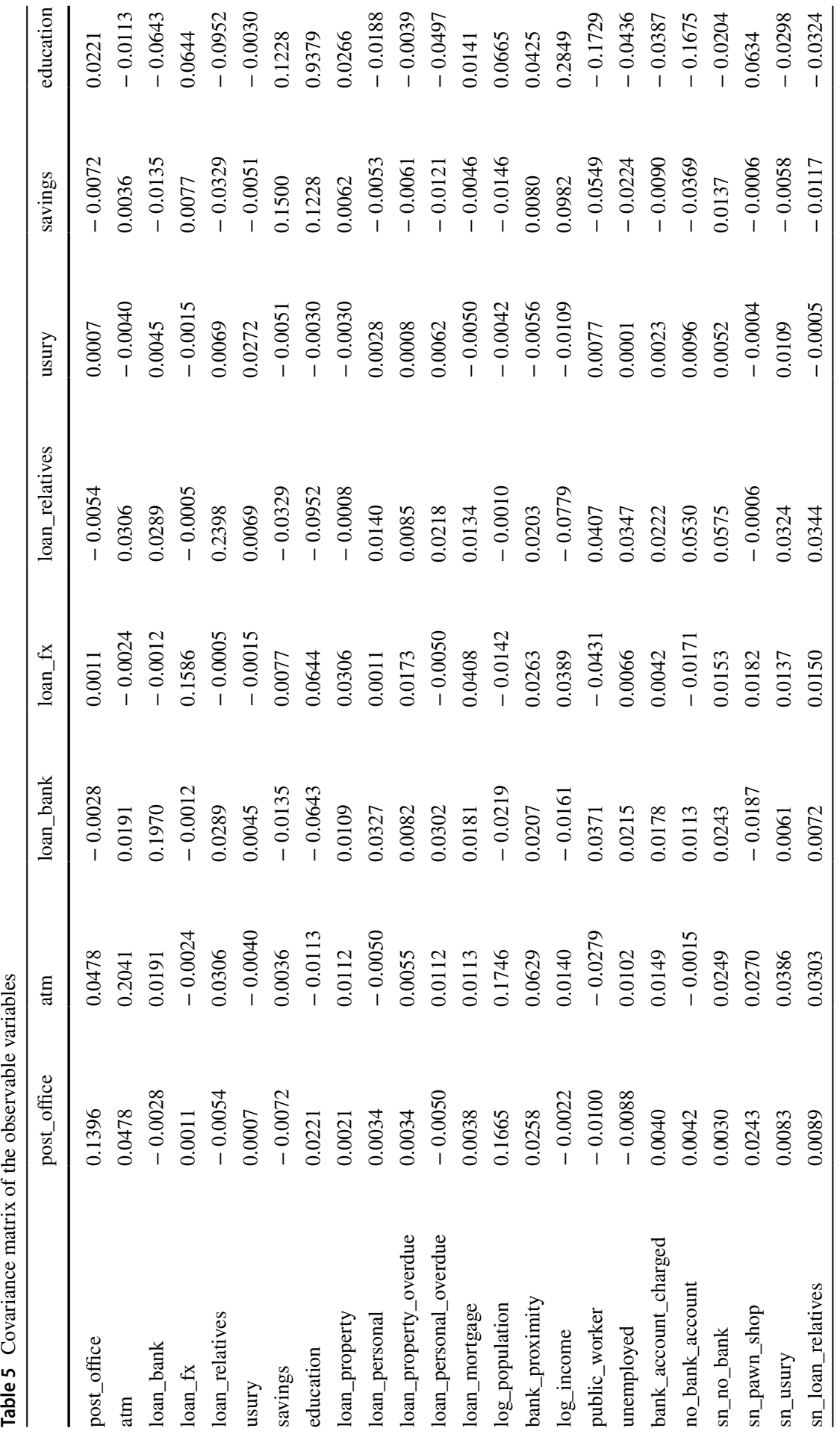

我这 


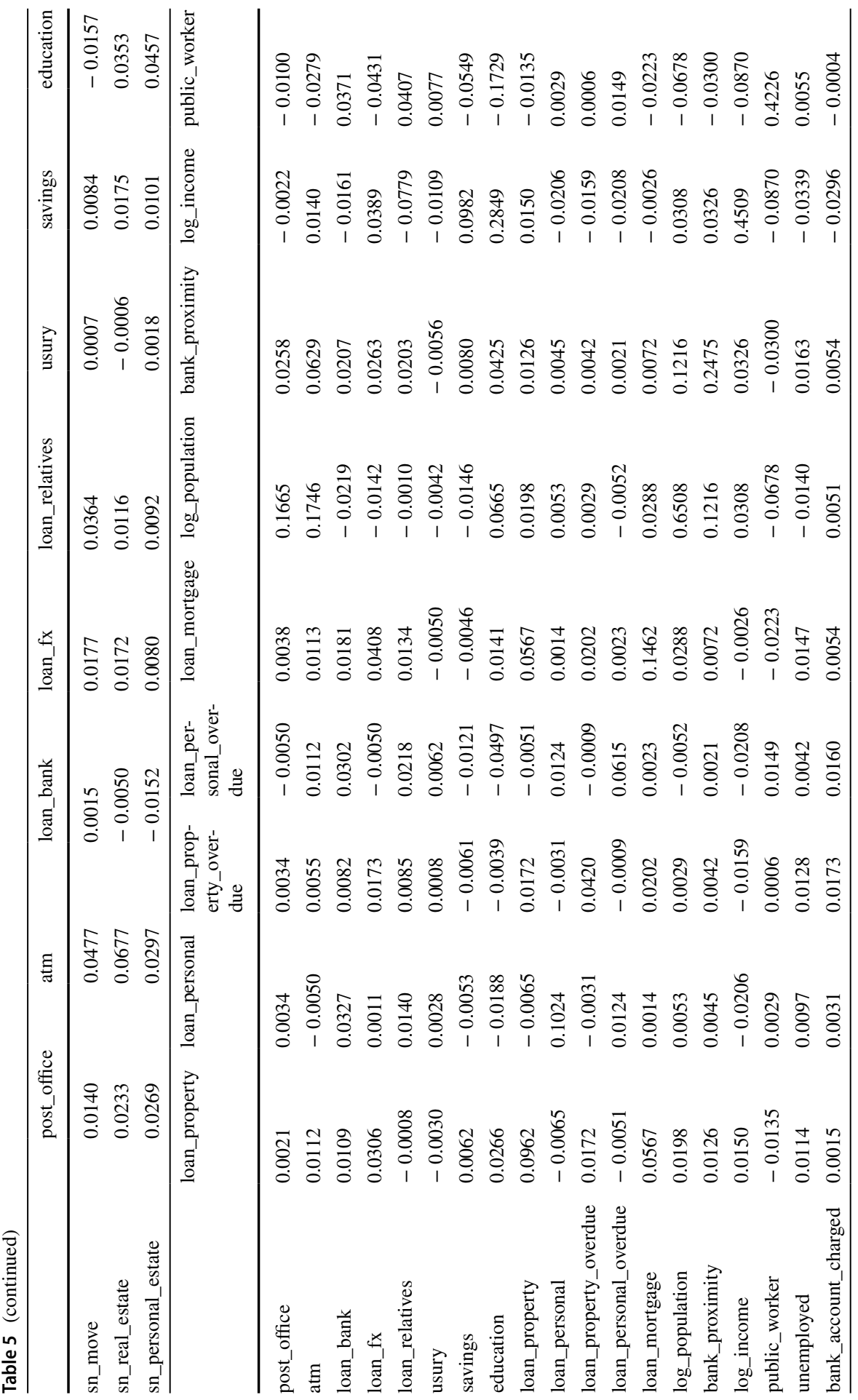




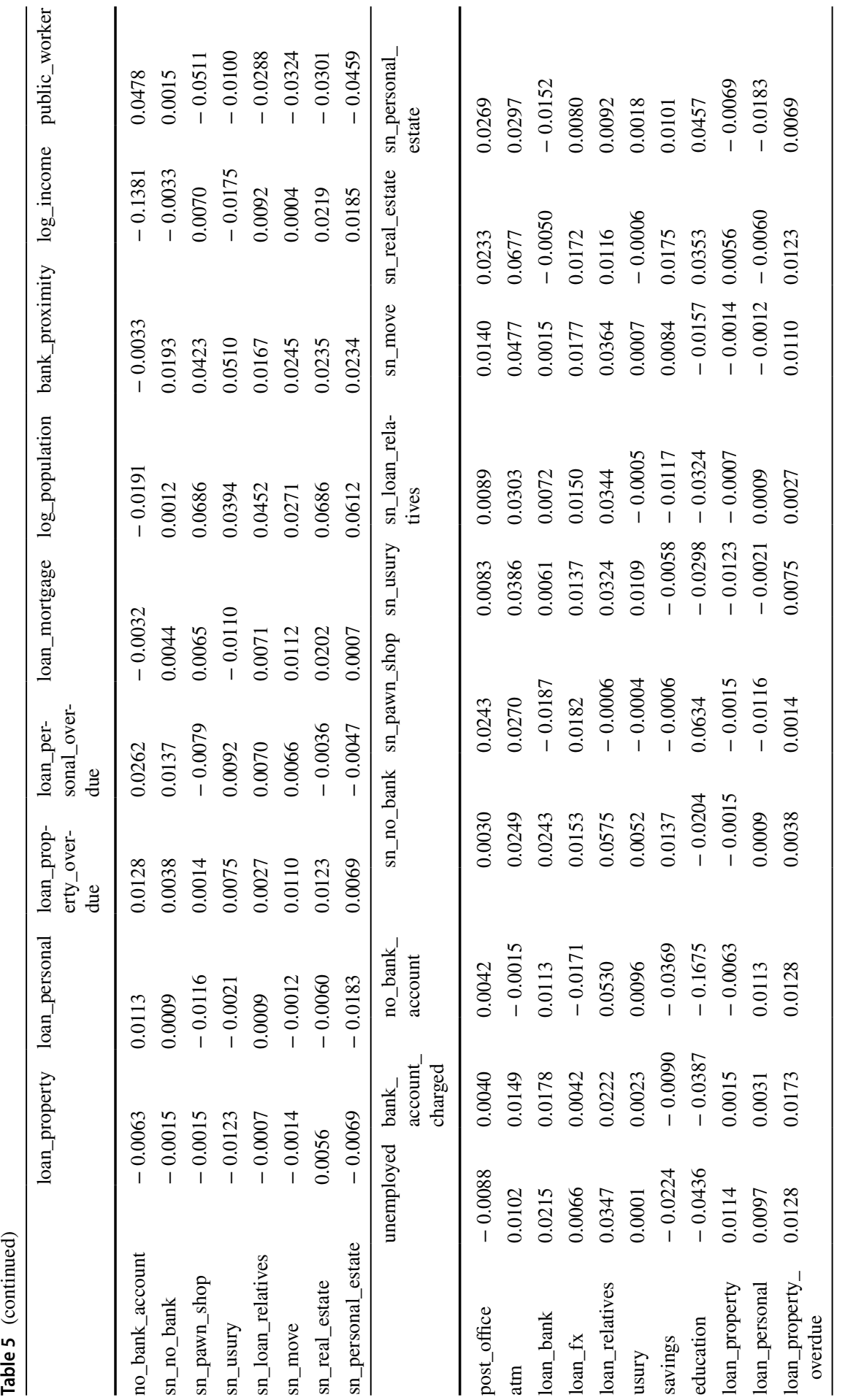




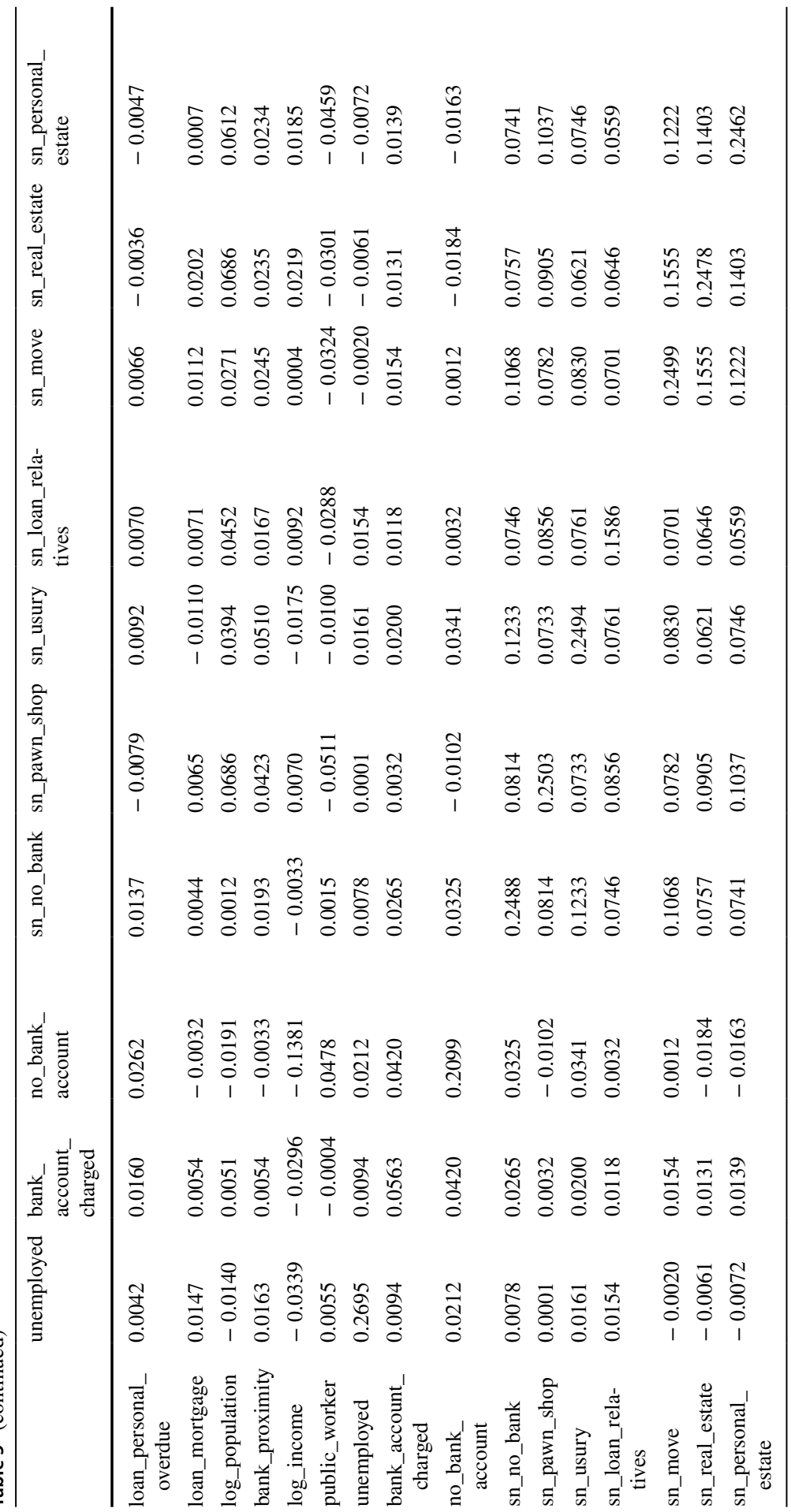


Table 6 Variable pairs of residual correlations

\begin{tabular}{lll}
\hline stloan & $\sim \sim$ & ltloan \\
\hline income & $\sim \sim$ & bankservice \\
sn_no_bank & $\sim \sim$ & sn_usury \\
bank_account_charged & $\sim \sim$ & loan_property_overdue \\
sn_real_estate & $\sim \sim$ & sn_move \\
log_population & $\sim \sim$ & post_office \\
sn_no_bank & $\sim \sim$ & sn_real_estate \\
sn_loan_relatives & $\sim ~$ & sn_pawn_shop \\
sn_usury & $\sim$ & sn_real_estate \\
sn_real_estate & $\sim ~$ & sn_personal_estate \\
no_bank_account & $\sim ~$ & log_income \\
sn_move & $\sim \sim$ & sn_personal_estate \\
sn_real_estate & $\sim ~$ & atm \\
sn_pawn_shop & $\sim ~$ & sn_personal_estate \\
no_bank_account & $\sim ~$ & bank_account_charged \\
sn_no_bank & $\sim ~$ & savings \\
no_bank_account & $\sim ~$ & education \\
\hline
\end{tabular}




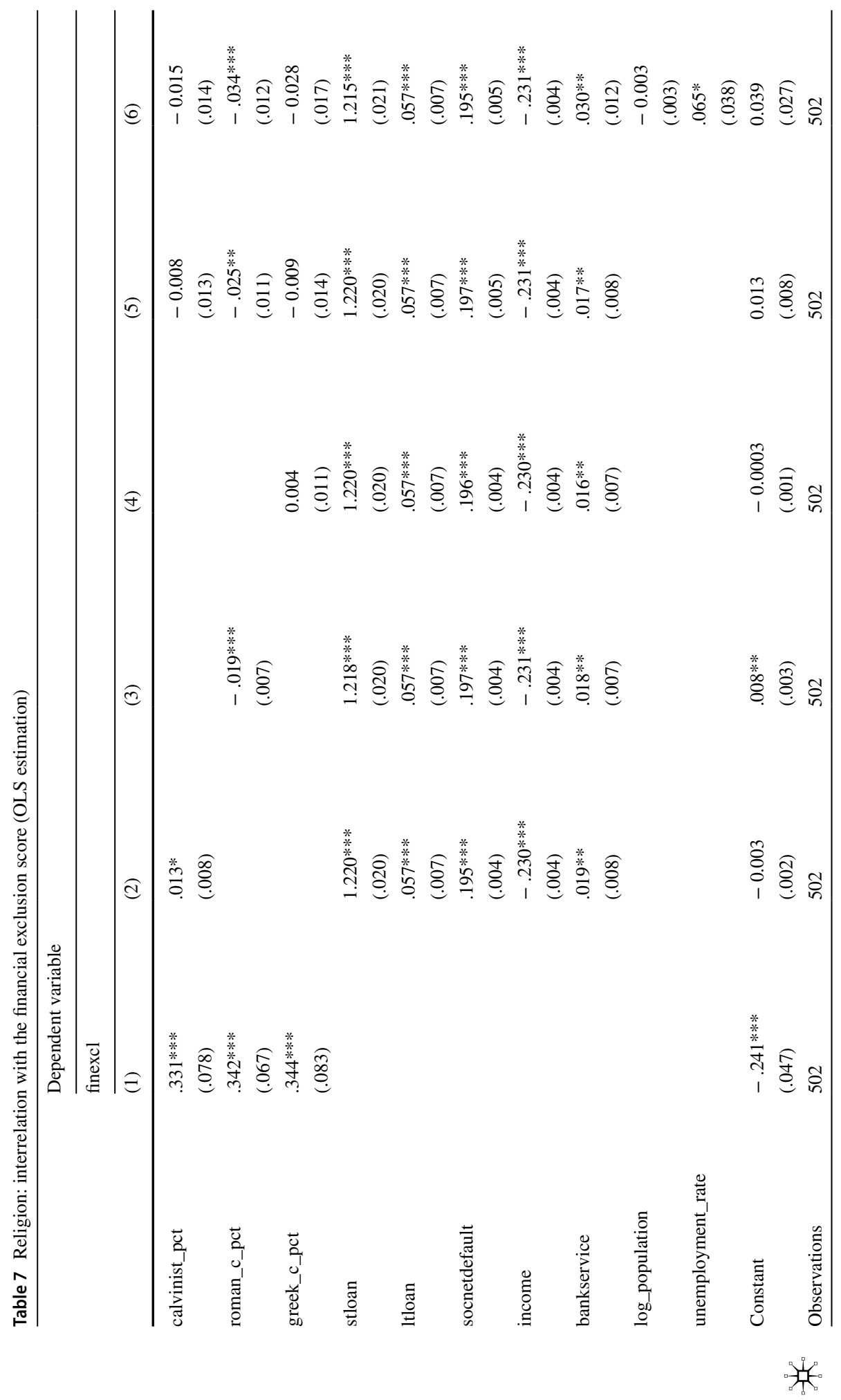




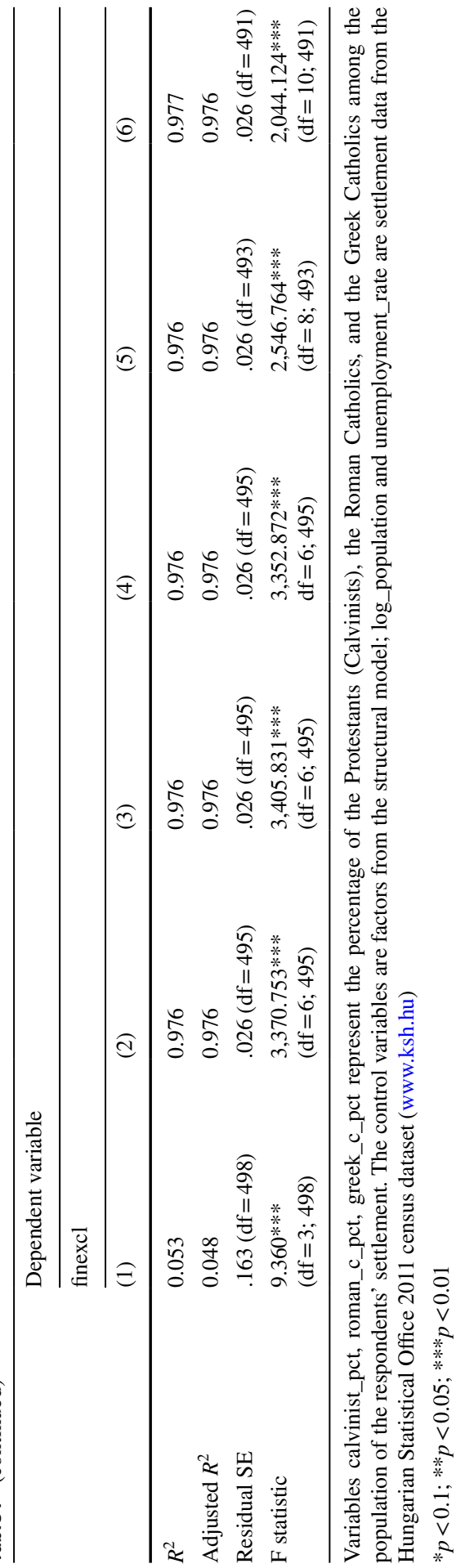

站。 


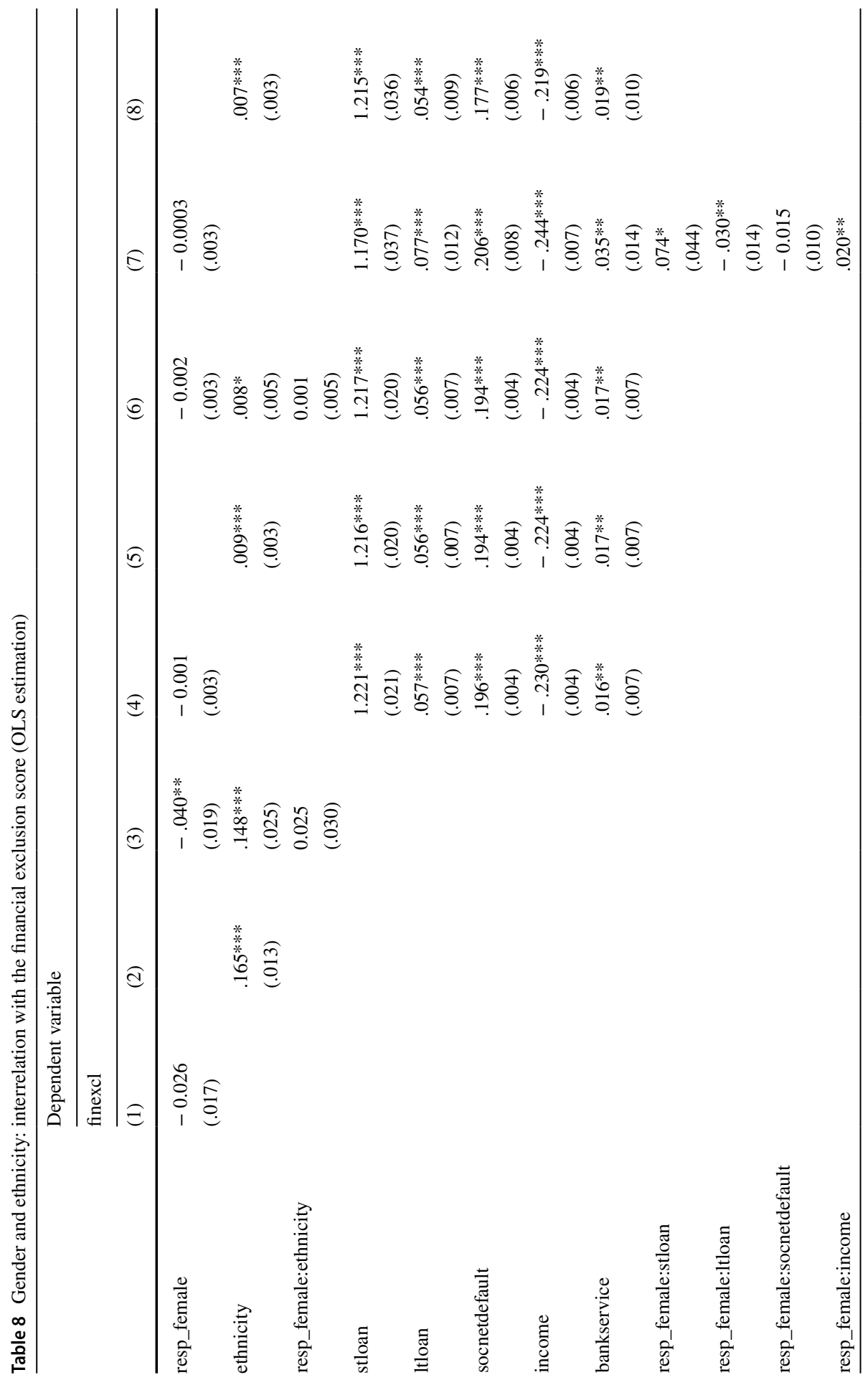




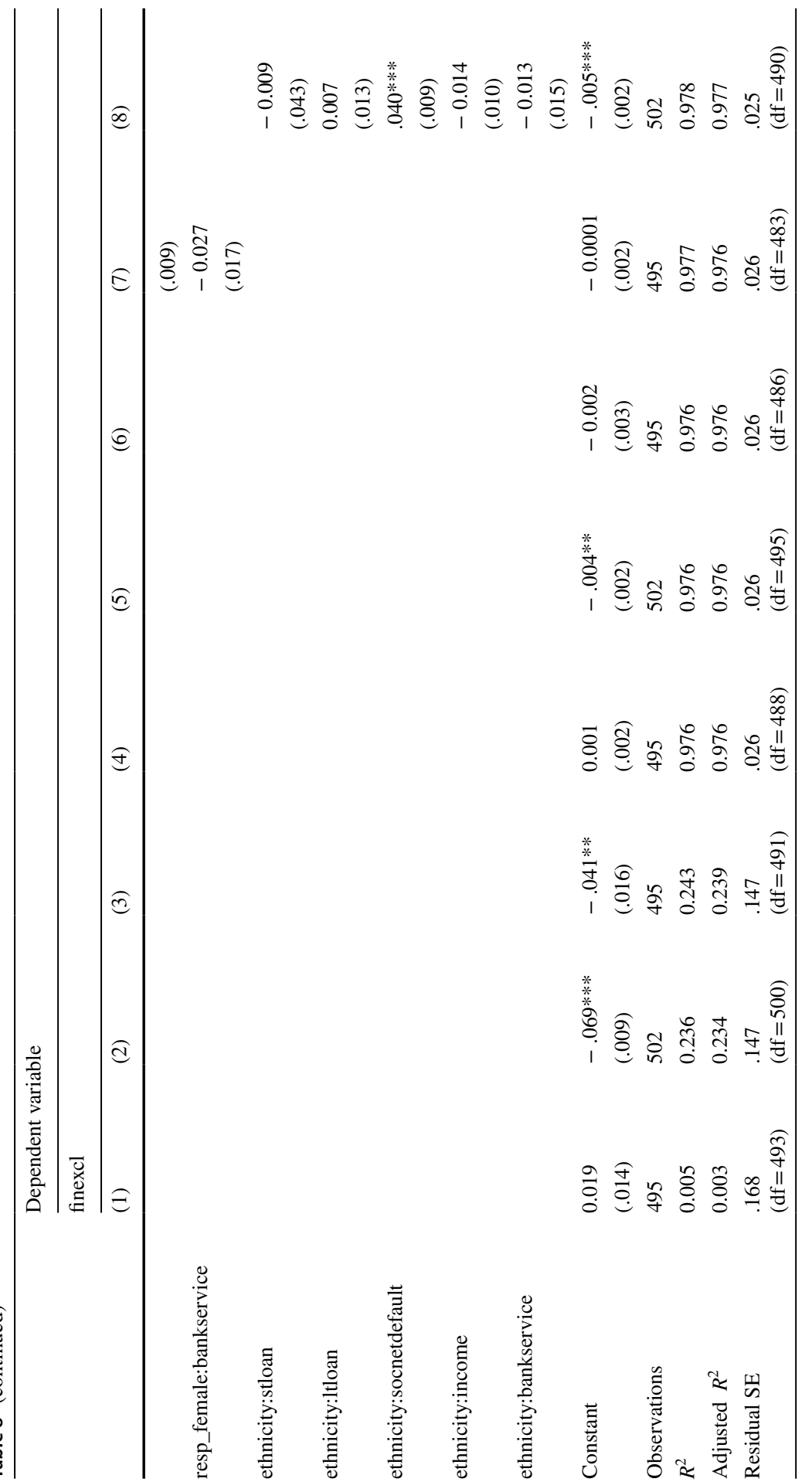

起。 


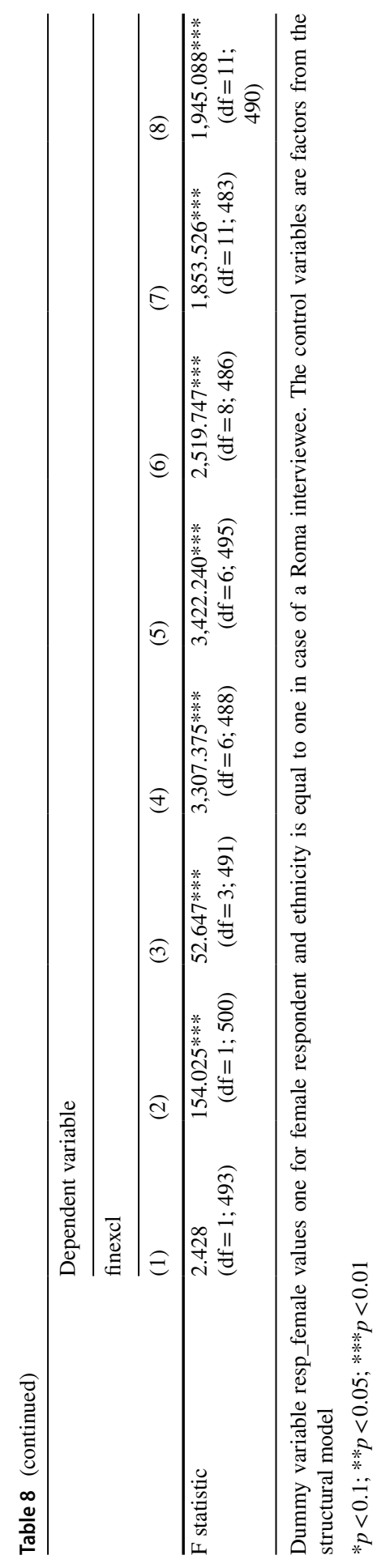


Table 9 Structural model for Roma and non-Roma sub-samples

\begin{tabular}{|c|c|c|c|c|c|c|c|c|}
\hline \multirow[t]{2}{*}{ Left-hand side } & & \multirow[t]{2}{*}{ Right-hand side } & \multicolumn{3}{|c|}{ Roma subsample $(N=211)$} & \multicolumn{3}{|c|}{$\begin{array}{l}\text { Non-Roma subsample } \\
(N=291)\end{array}$} \\
\hline & & & Est std & SE & $p$ value & Est std & $\mathrm{SE}$ & $p$ value \\
\hline finexcl & $\sim$ & stloan & .674 & .240 & $.005^{* *}$ & .692 & .405 & .087 \\
\hline finexcl & $\sim$ & ltloan & .149 & .158 & .348 & -.046 & .190 & .807 \\
\hline finexcl & $\sim$ & socnetdefault & .626 & .208 & $.003 * *$ & .011 & .222 & .959 \\
\hline finexcl & $\sim$ & income & -.223 & .293 & .446 & -.493 & .298 & .098 \\
\hline finexcl & $\sim$ & bankservice & -.073 & .207 & .723 & .040 & .154 & .797 \\
\hline stloan & $\sim$ & income & -.301 & .125 & $.016^{*}$ & -.479 & .097 & $0 * * *$ \\
\hline stloan & $\sim$ & bankservice & .137 & .176 & .436 & .233 & .201 & .246 \\
\hline stloan & $\sim$ & socnetdefault & -.045 & .178 & .800 & .084 & .124 & .500 \\
\hline ltloan & $\sim$ & income & .418 & .261 & .109 & -.014 & .098 & .885 \\
\hline ltloan & $\sim$ & bankservice & .166 & .119 & .165 & .020 & .090 & .823 \\
\hline ltloan & $\sim$ & socnetdefault & 0 & .149 & .998 & .066 & .090 & .464 \\
\hline socnetdefault & $\sim$ & income & -.015 & .255 & .952 & .113 & .098 & .251 \\
\hline socnetdefault & $\sim$ & bankservice & .447 & .080 & $0 * * *$ & .234 & .102 & $.022 *$ \\
\hline
\end{tabular}

Measurement model tests are as follows: RMSEA $=0.053, \mathrm{CFI}=0.854$, chi square $=471.256, \mathrm{df}=294$, $p$ value $=0$ (Roma subsample), $\mathrm{RMSEA}=0.041, \mathrm{CFI}=0.891$, chi square $=438.524, \mathrm{df}=294, p$ value $=0$ (non-Roma subsample)

Est std estimated standardised coefficient, $S E$ robust standard error (Huber-White)

$p<0.001$ : $^{* *}, 0.001<p<0.01$ : $^{*}, 0.01<p<0.05:^{*}, p<0.05<p<0.10$ 
Table 10 Revealing some spillovers of financial exclusion: group means of financial exclusion scores

\begin{tabular}{|c|c|c|c|c|c|}
\hline Variable & Category & $n$ & Mean & SE & $p$ value \\
\hline \multirow[t]{11}{*}{ Job market status } & Unregistered job status & 11 & 0.2547 & 0.0543 & $0.0009 * * *$ \\
\hline & Inactive & 16 & 0.1526 & 0.0461 & $0.0048 * *$ \\
\hline & Public worker & 130 & 0.0630 & 0.0149 & $0.0000 * * *$ \\
\hline & Unemployed & 47 & 0.0430 & 0.0236 & 0.0755 \\
\hline & On maternity & 48 & 0.0307 & 0.0275 & 0.2696 \\
\hline & Other & 16 & -0.0014 & 0.0385 & 0.9713 \\
\hline & Pensioner & 47 & -0.0285 & 0.0202 & 0.1644 \\
\hline & Part-time job & 12 & -0.0344 & 0.0432 & 0.4429 \\
\hline & Full-time job & 167 & -0.0852 & 0.0082 & $0.0000 * * *$ \\
\hline & Working abroad & 1 & -0.1275 & NA & NA \\
\hline & Pupil & 6 & -0.1349 & 0.0630 & 0.0853 \\
\hline \multirow[t]{5}{*}{ Health satisfaction } & Very unsatisfied & 31 & 0.0406 & 0.0313 & 0.2053 \\
\hline & So-so & 114 & 0.0362 & 0.0156 & $0.0218^{*}$ \\
\hline & Rather unsatisfied & 86 & 0.0328 & 0.0199 & 0.1026 \\
\hline & Rather satisfied & 183 & -0.0176 & 0.0122 & 0.1503 \\
\hline & Very satisfied & 88 & -0.0566 & 0.0141 & $0.0001 * * *$ \\
\hline \multirow[t]{6}{*}{ Future outlooks } & Very unsatisfied & 31 & 0.1193 & 0.0343 & $0.0016^{* *}$ \\
\hline & Rather unsatisfied & 107 & 0.0462 & 0.0151 & $0.0028 * *$ \\
\hline & So-so & 203 & 0.0040 & 0.0119 & 0.7373 \\
\hline & Very satisfied & 40 & -0.0275 & 0.0255 & 0.2870 \\
\hline & Rather satisfied & 112 & -0.0690 & 0.0132 & $0.0000 * * *$ \\
\hline & Does not know & 9 & -0.0693 & 0.0439 & 0.1533 \\
\hline \multirow[t]{6}{*}{ Being up and coming } & Never & 72 & 0.0904 & 0.0215 & $0.0001 * * *$ \\
\hline & One or two days in a week & 147 & 0.0610 & 0.0138 & $0.0000 * * *$ \\
\hline & No answer & 1 & 0.0377 & NA & NA \\
\hline & More than half of the days & 139 & -0.0364 & 0.0134 & $0.0076^{* *}$ \\
\hline & Does not know & 7 & -0.0654 & 0.0380 & 0.1356 \\
\hline & Almost everyday & 136 & -0.0735 & 0.0104 & $0.0000 * * *$ \\
\hline \multirow[t]{4}{*}{ Water supply } & $\begin{array}{l}\text { Yes, formerly, but now it is } \\
\text { available }\end{array}$ & 37 & 0.1645 & 0.0329 & $0.0000 * * *$ \\
\hline & Yes, and presently is turned off & 12 & 0.1369 & 0.0511 & $0.0215^{*}$ \\
\hline & No answer & 83 & 0.1278 & 0.0199 & $0.0000 * * *$ \\
\hline & Never & 370 & -0.0496 & 0.0067 & $0.0000 * * *$ \\
\hline \multirow[t]{3}{*}{ Electricity supply } & $\begin{array}{l}\text { Yes, formerly, but now it is } \\
\text { available }\end{array}$ & 103 & 0.1656 & 0.0182 & $0.0000 * * *$ \\
\hline & Yes, and presently is turned off & 11 & 0.1310 & 0.0464 & $0.0181^{*}$ \\
\hline & Never & 388 & -0.0477 & 0.0066 & $0.0000 * * *$ \\
\hline Formal financial exclusion score & & 502 & 0.0000 & 0.1675 & \\
\hline
\end{tabular}

Number of observations $(n)$, mean, standard errors (SE) and $p$ values ( $p$ value) two-sided $t$ test (null is the mean equals to zero) are detailed by category groups. The higher the formal financial exclusion value, the closer the household is to financial exclusion

$p<0.001$ : $* *, 0.001<p<0.01: * *, 0.01<p<0.05: *, p<0.05<p<0.10^{*}$ 
Acknowledgements This research is supported by the Higher Education Institutional Excellence Program of the Ministry of Innovation and Technology in the framework of the 'Financial and Public Services' research project (NKFIH-1163-10/2019) at Corvinus University of Budapest. The authors thank their colleagues who designed the survey panel questions under the 'Financial and Public Services' research project: Balázs Bazsalya, Edina Berlinger, Hubert János Kiss, György Molnár and Gábor Neszveda.

Funding Open access funding provided by Corvinus University of Budapest.

Open Access This article is licensed under a Creative Commons Attribution 4.0 International License, which permits use, sharing, adaptation, distribution and reproduction in any medium or format, as long as you give appropriate credit to the original author(s) and the source, provide a link to the Creative Commons licence, and indicate if changes were made. The images or other third party material in this article are included in the article's Creative Commons licence, unless indicated otherwise in a credit line to the material. If material is not included in the article's Creative Commons licence and your intended use is not permitted by statutory regulation or exceeds the permitted use, you will need to obtain permission directly from the copyright holder. To view a copy of this licence, visit http://creativecommons.org/licen ses/by/4.0/.

\section{References}

Adegbite, Olayinka O., and Charles L. Machethe. 2020. Bridging the financial inclusion gender gap in smallholder agriculture in Nigeria: An untapped potential for sustainable development. World Development. https://doi.org/10.1016/j.worlddev.2019.104755.

Ahunov M., and Van Hove, L. 2020. National culture and (dis)trust in banks: Cross-country evidence. Economic Notes 49 (3). https://doi.org/10.1111/ecno.12165

Anderloni, Luisa, Bernard Bayot, Piotr Błędowski, Małgorzata Iwanicz-Drozdowska, and Elaine Kempson. 2008. Financial services provision and prevention of financial exclusion. European Commission, Directorate-General for Employment, Social Affairs and Equal Opportunities. http://ec.europa.eu/employment_social/spsi.

Anderloni, Luisa, and Emanuele Carluccio. 2006. Access to bank accounts and payment services. In: New frontiers in banking services: Emerging needs and tailored products for untapped markets, 5-105 Berlin: Springer. https://doi.org/10.1007/978-3-540-46498-3_2.

Banerjee, A., and E. Duflo. 2007. The economic lives of the poor. Journal of Economic Perspectives 21 (1): 141-168.

Beck, T., and Brown, M. 2011. Which households use banks? Evidence from the transition economies. Working Paper 1295. ECB Working Paper Series. Frankfurt: European Central Bank. https://www.ecb.europa.eu/pub/pdf/scpwps/ecbwp1295.pdf.

Bentler, P. M. 1989. EQS structural equations program manual. BMDP Statistical Software.

Bernstein, A. 2015. Household debt overhang and labor supply. SSRN Electronic Journal. https://doi. org/10.2139/ssrn.2700781.

Bhalla, A.S., and F. Lapeyre. 1999. Global integration and social exclusion with special reference to Poland and Hungary. The European Journal of Development Research 11 (1): 101-124. https:// doi.org/10.1080/09578819908426729.

Big Lottery Fund. 2018. Big lottery fund annual report and accounts 2017-18. London: Big Lottery Fund. www.gov.uk/government/publications.

Bollen, K. A. 1989. Confirmatory factor analysis. In Structural equations with latent variables, 226-318. Wiley. https://doi.org/10.1002/9781118619179.ch7

Browne, M.W., and Cudeck, R. 1992. Alternative ways of assessing model fit. Sociological Methods \& Research 21(2): 230-258. https://doi.org/10.1177/0049124192021002005

Campbell, J.Y. 2006. Household finance. Journal of Finance 61 (4): 1553-1604. https://doi.org/10. 1111/j.1540-6261.2006.00883.x.

Chen, M. 2014. Informal employment and development: Patterns of inclusion and exclusion. The European Journal of Development Research 26 (4): 397-418. https://doi.org/10.1057/ejdr.2014. 31. 
Cherednychenko, O.O., and J.M. Meindertsma. 2019. Irresponsible lending in the post-crisis era: Is the EU consumer credit directive fit for its purpose? Journal of Consumer Policy 42 (4): 483-519. https://doi.org/10.1007/s10603-019-09421-4.

Csizmady, A., and Hegedüs, J. 2016. Hungarian Mortgage Rescue Programs 2009-2016 (August 9, 2016). The Narodowy Bank Polski Workshop: Recent Trends in the Real Estate Market and Its Analysis - 2015 Edition, Available at SSRN: https://ssrn.com/abstract=2841632.

D'Alessio, G., and Iezzi, S. 2013. Household over-indebtedness-definition and measurement with Italian data. In Proceedings of the Sixth IFC Conference On, edited by Bank for International Settlements, vol. 36, 496-517. Bank for International Settlements. https://EconPapers.repec.org/ RePEc:bis:bisifc:36-33.

Danyi, G., and A. Vigvári. 2019. Túlélés, ellenállás, adaptáció: Informális gyakorlatok magyarországon és lengyelországban. Replika 110: 11-31. https://doi.org/10.32564/110.2.

Disney, R., S. Bridges, and J. Gathergood, J. (2008) Drivers of over-indebtedness: Report to the department for business, enterprise and regulatory reform. Centre for Policy Evaluation Research Report.

Dobbie, W., and J. Song. 2015. Debt relief and debtor outcomes: Measuring the effects of consumer bankruptcy protection. The American Economic Review 105 (3): 1272-1311.

Eurostat. 2019. Civic consulting based on Eurostat, SILC data. http://appsso.eurostat.ec.europa.eu/nui/ show.do?dataset=ilc_mdes05\&lang=en.

Fay, S., E. Hurst, and M.J. White. 2002. The Household bankruptcy decision. American Economic Review 92 (3): 706-718. https://doi.org/10.1257/00028280260136327.

Fleck, G., and T. Virág. 2000. Élet a bodza utcában: Partos beás közössége. In: A romák/cigányok és a láthatatlan gazdaság, ed István Kemény, 81-139. Budapest: Gondolat.

Fondeville, N., Ôzdemir, E., and Ward, T. 2010. Financial exclusion in the EU. New evidence from the EU-SILC special module (Research Note No. 3; Social Situation Observatory - Income Distribution and Living Condition). European Commission, Directorate-General for Employment, Social Affairs and Equal Opportunities. https://ec.europa.eu/social/BlobServlet?docId=9816\&langId=en

Garðarsdóttir, R.B., and H. Dittmar. 2012. The relationship of materialism to debt and financial wellbeing: The case of Iceland's perceived prosperity. Journal of Economic Psychology 33 (3): 471481. https://doi.org/10.1016/j.joep.2011.12.008.

Gilligan, A.M., D.S. Alberts, D.J. Roe, and G.H. Skrepnek. 2018. Death or debt? National estimates of financial toxicity in persons with newly-diagnosed cancer. The American Journal of Medicine 131 (10): 1187-1199.e5. https://doi.org/10.1016/j.amjmed.2018.05.020.

Glaeser, E.L., D.I. Laibson, J.A. Scheinkman, and C.L. Soutter. 2000. Measuring trust. The Quarterly Journal of Economics 115 (3): 811-846. https://doi.org/10.1162/003355300554926.

Gosztonyi, M. 2017. Jugglers of money Results of a participatory action research. The Indian Journal of Social Work 78 (1): 75-92.

Guiso, L., P. Sapienza, and L. Zingales. 2003. People's opium? Religion and economic attitudes. Journal of Monetary Economics 50 (1): 225-282.

Hajdu, O. 2009. Poverty, deprivation, exclusion: A structural equations modelling approach. Hungarian Statistical Review 87 (13): 90-102.

Hilgert, M.A., J.M. Hogarth, and S.G. Beverly. 2003. Household financial management: The connection between knowledge and behavior. Federal Reserve Bulletin 88 (7): 309-322.

Hoyle, R.H., and A.T. Panter. 1995. Writing about structural equation models. In Structural equation modeling: Concepts, issues, and applications, ed. R.H. Hoyle, 158-176. Thousand Oaks, CA: Sage Publications.

Jain, S. 1999. Symbiosis vs. crowding-out: The interaction of formal and informal credit markets in developing countries. Journal of Development Economics 59 (2): 419-444.

Johnson, K.W. 1999. Structural equation modeling in practice. Journal of Social Service Research 24(34): 131-171. https://doi.org/10.1300/J079v24n03_06

Keese, M. 2009. Triggers and determinants of severe household indebtedness in Germany. SOEP papers on Multidisciplinary Panel Data Research 239. DIW Berlin, The German Socio-Economic Panel (SOEP). https://EconPapers.repec.org/RePEc:diw:diwsop:diw_sp239.

Kilborn, J.J. 2005. Behavioral economics, overindebtedness \& comparative consumer bankruptcy: Searching for causes and evaluating solutions. Emory Bankruptcy Developments Journal. https:// repository.jmls.edu/cgi/viewcontent.cgi?article $=1110 \&$ context=facpubs. 
Kim, D-W., Yu, J.-S., Hassan, M. K. 2020. The influence of religion and social inequality on financial inclusion. The Singapore Economic Review 65 (1): 193-216. https://doi.org/10.1142/S021759081 7460031

Kostov, P., A. Thankom, and S. Annim. 2012. Determinants of access to finance: An investigation into the Mzansi intervention. The European Journal of Development Research 24 (3): 397-412.

Kovai, C. 2017. A Cigány-Magyar Különbségtétel És a Rokonság. Budapest: L’Harmattan.

Kuhnen, C.M., and B.T. Melzer. 2018. Noncognitive abilities and financial delinquency: The role of self-efficacy in avoiding financial distress. The Journal of Finance 73 (6): 2837-2869. https:// doi.org/10.1111/jofi.12724.

Lea, S.E.G., P. Webley, and C.M. Walker . 1995. Psychological factors in consumer debt: Money management, economic socialization, and credit use. Journal of Economic Psychology 16 (4): 681-701.

Leyshon, A., and N. Thrift. 1996. Financial exclusion and the shifting boundaries of the financial system. Environment and Planning a: Economy and Space 28 (7): 1150-1156. https://doi.org/10. 1068/a281150.

Lombardi, M. J., M. Mohanty, and I. Shim. 2017. The real effects of household debt in the short and long run. Bank for International Settlements. https://ideas.repec.org/p/bis/biswps/607.html.

Lusardi, A., and P. Tufano. 2009. Debt literacy, financial experiences, and overindebtedness. National Bureau of Economic Research Working Paper Series No. 14808. https://doi.org/10.3386/w14808.

MacCallum, R.C., Roznowski, M., and Necowitz, L.B. 1992. Model modifications in covariance structure analysis: The problem of capitalization on chance. Psychological Bulletin 111(3): 490-504. https:// doi.org/10.1037/0033-2909.111.3.490

Mahoney, N. 2015. Bankruptcy as implicit health insurance. American Economic Review 105 (2): 710-746. https://doi.org/10.1257/aer.20131408.

Martin-Oliver, A. 2019. Financial exclusion and branch closures in Spain after the Great Recession. Regional Studies 53 (4): 562-573. https://doi.org/10.1080/00343404.2018.1462485.

Micklitz, H.W., and I. Domurath, I. (eds.) 2015. Consumer debt and social exclusion in Europe. 1st ed. Markets and the Law. Ashgate Publishing. https://www.crcpress.com/Consumer-Debt-andSocial-Exclusion-in-Europe/Micklitz-Domurath/p/book/9781472449030\#googlePreviewContain er.

Muthén, B. O., and Muthén, L. K. 2004. Mplus User's Guide. Statistical analysis with latent variables: User's guide. http://www.statmodel.com/techappen.shtml

Norvilitis, J.M., M.M. Merwin, T.M. Osberg, P.V. Roehling, P. Young, and M.M. Kamas. 2006. Personality factors, money attitudes, financial knowledge, and credit-card debt in college students. Journal of Applied Social Psychology 36 (6): 1395-1413. https://doi.org/10.1111/j.0021-9029. 2006.00065.x.

Parise, G., and K. Peijnenburg. 2019. Noncognitive abilities and financial distress: Evidence from a representative household panel. The Review of Financial Studies 32 (10): 3884-3919. https://doi. org/10.1093/rfs/hhz010.

Rinaldi, L., and A. Sanchis-Arellano. 2006. Household debt sustainability: What explains household non-performing loans? An empirical analysis. Working Paper 570. ECB Working Paper Series. Frankfurt: European Central Bank. https://www.ecb.europa.eu/pub/pdf/scpwps/ecbwp570.pdf.

Rosseel, Y. 2012. Journal of Statistical Software 48(2). https://doi.org/10.18637/jss.v048.i02

Ruesga-Benito, S.M., F. González-Laxe, and X. Picatoste. 2018. Sustainable development, poverty, and risk of exclusion for young people in the European Union: The case of NEETs. Sustainability 10 (12): 1-15.

$\mathrm{Xu}, \mathrm{X}$. 2020. Trust and financial inclusion: A cross-country study. Finance Research Letters. https:// doi.org/10.1016/j.frl.2019.101310.

Yah, N.C., and E.C. Mbotta Ntjen. 2018. Determinants of inclusive financial development in Africa. Journal of Economics and Development Studies 6 (3): 36-46. https://doi.org/10.15640/jeds.v6n3a5.

Zins, A., and L. Weill. 2016. The determinants of financial inclusion in Africa. Review of Development Finance 6 (1): 46-57. https://doi.org/10.1016/j.rdf.2016.05.001.

Publisher's Note Springer Nature remains neutral with regard to jurisdictional claims in published maps and institutional affiliations. 